\title{
INTEGRATED SOCIAL SERVICES BASED ON PRESERVATION AND PROMOTION OF COMMUNITY HEALTH: AN ANALYSIS OF THE STATE AND PROSPECTS OF DEVELOPMENT
}

\author{
Liliia $\mathrm{Klos}^{1}$, Nataliia Nazar ${ }^{2}$ \\ Lviv National Polytechnic University, Lviv, Ukraine
}

\begin{abstract}
.
Introduction: At the final stage of administrative-territorial reform in Ukraine, it is important to realistically assess the social needs and social problems that exist in newly created territorial communities. Territorial communities should be based on healthy families and healthy individuals, whose initiative will help ensure the continued social development of the community. In its turn, the community should be built on the principles of friendly to its own citizens, meeting their needs, first of all, the needs of the least protected categories children, people with disabilities and chronic diseases, elderly people. Therefore, integrated social services based on the principles of preserving and promoting health are a tool for solving social problems in the community (Klos, Khudoba, Shkoliar, 2019, p. 26).
\end{abstract}

Purpose. The purpose of the study is to show the importance of using integrated social services in the community based on the principles of preservation and promotion of health as an important means of promoting territorial community development and social development of the country.

Methods. The study used theoretical methods of research, in particular, the search and collection of statistical information on the formation, normalization and approval of the composition of territorial communities; collection and analysis of sources on the problem of social services and social protection of the population of territorial communities; systematization of sources and their analysis by blocks of tasks; analysis, comparison, synthesis and implementation of the results of the study of social services based on the principles of promoting and preserving community health.

Results. Within the framework of the U-LEAD Program with Europe and the ICO Partnership Every Child, the project "Community for Human: Enhancing Communities' Competence for the Development of Social Services" and 
understanding the peculiarities of organizing social support for vulnerable segments of the UTC population through the implementation of the social services model. Among the objectives of the project were, inter alia, to study the status of providing local communities with social workers, the range of social services provided in the community, taking into account the real needs of the population in social assistance (ICO Partnership for Every Child, 2019, p. 5-6).

The study covered 245 projected territorial communities in Ukraine. Because most communities did not have the information to make appropriate decisions about the services they needed, a special methodology was used to assess the needs of the population in social services. An appropriate tool for monitoring the needs of the population in social services was developed and tested at the Oxford Policy Management Consortium with the participation of the Every Child Partnership, in collaboration with UNICEF, and with financial support from the European Union. The aggregate index of providing the population with social services of the population of the UTC is determined by the set of indicators: the index of provision of social services for children and families with children; index of provision of social care services for orphans and children deprived of family care; the index of provision of social services for the elderly; index of provision of social services for persons with disabilities; index of provision of social services to persons in need of adaptation and integration (reintegration); index of provision of social services to persons in need of emergency or crisis intervention (ICO Partnership for Every Child, 2019, p. 28).

Mostly communities use the resource of available social services already at their disposal, their range is limited and needs improvement and review, taking into account real social problems and needs of consumers. An important tool for addressing the issues that are relevant to UTC members is those based on the principles of preserving and promoting health. In particular, social prevention, community representation services, crisis and emergency intervention, social support / patronage, asylum, home care, day care, supported living.

Conclusion: The study of the results of the mentioned project and the current state of providing territorial communities with social services lead to the conclusion that there is a high level of community needs for social work professionals who are able and able to provide integrated social services in the 
community on the grounds of preservation and promotion of health. To do this, professional training of skilled social workers for the provision of integrated social services in the community should be stepped up.

Keywords: social worker, community, integrated social services, health preservation and promotion

The authors declare that they have no competing interests

\section{References}

ICO Partnership for Every Child (2019). All-Ukrainian seminar "Preparation of social workers for the development of integrated social services in ATS". Retrieved from URL: http://p4ec.org.ua

Ilchuk, L. (2018). Development of a system of integrated social services in the context of decentralization (for example, united territorial communities). Restored from http://www.ir.kneu.edu.ua/bitstream/handle/2010/24760/Ilchuk. pdf?sequence=1\&amp;isAllowed =y

Klos, L., Khudoba, O., Shkoliar, M. (2019). A New Look at Addressing Health Issues in a Territorial Community: An Interdisciplinary Team of Professionals. Partnerships for Social Change: 20 Years of Experience ", dedicated to the 20th anniversary of Canada-Ukraine" Reforming Social Services "Project (1999-2003): international scientific and practical conference (Lviv, 24-26 October 2019): proceedings. Rome, 1 (3), 25-29.

Law of Ukraine "On Social Services" (2019). Restored from Ошибка! Недопустимый объект гиперссылки.

Popic, Y. (2016). Organization of activities of integrated social services in territorial communities. Scientific Bulletin of Uzhgorod National University. Series: Pedagogy. Social Work, 2, 193-196. Restored from http://nbuv.gov.ua/UJRN/Nvuuped_2016_2_52

Training materials of the All-Ukrainian Seminar (2019). "Preparing Social Workers for the Development of Integrated Social Services in OGT" developed by experts of the project Community for Human: Enhancing Communities' Competence for the Development of Social Services, implemented by the Every Child Partnership with the support of the ULEAD Program with Europe

Zvereva, I. D., Petrochko, Zh. V. (Eds.). (2007). Integrated Social Services: Theory, Practice, Innovation: Restored from http://www.p4ec.org.ua/upload/education /library/1345188352.pdf 
Інтегровані соціальні послуги на засадах здоров'сзбереження в громаді: аналіз стану і перспективи розвитку

\author{
Лілія Клос ${ }^{1}$, Наталія Назар ${ }^{2}$ \\ Національний університет «Львівська політехніка» \\ 1 доктор педагогічних наук, доцент, в.о.завідувача кафедри соціології та \\ 2 магістр соціальної роботи, студентка 3 року програми підготовки докторів \\ філософії за спеціальністю «Соціальна робота», Національний університет
} соціальної роботи, Національний університет «Львівська політехніка» «Львівська політехніка»

Ключові слова: соціальний працівник, громада, інтегровані соціальні послуги, збереження і зміцнення здоров'я

Вступ. На завершальному етапі проведення адміністративнотериторіальної реформи в Україні важливо реалістично оцінити соціальні потреби і соціальні проблеми, які існують у новостворених територіальних громадах. Основу територіальних громад мають становити здорові сім’ї і здорові індивіди, ініціатива яких допоможе забезпечити неперевний соціальний розвиток громади. Своєю чергою, громада має будуватися на засадах дружніх до власних громадян, задоволення їхніх потреб, в першу чергу, потреб найменш захищених категорій - дітей, людей з інвалідністю та хронічними захворюваннями, осіб похилого віку. Тому інструментом вирішення соціальних проблем в громаді $є$ інтегровані соціальні послуги, побудовані на засадах здоров’єзбереження (Клос, Худоба, Школяр, 2019, c.26).

Метою дослідження було показати важливість застосування інтегрованих соціальних послуг в громаді, заснованих на принципах збереження і зміцнення здоров'я, як важливого засобу сприяння розвитку територіальної громади і соціального розвитку країни.

Виклад основної частини. У межах Програми «U-LEAD з Свропою» та МБО «Партнерство «Кожній дитині» реалізувався проект «Громада для людини: підвищення компетентності громад для розвитку соціальних послуг» та розуміння особливостей організації соціальної підтримки вразливих верст населення в ОТГ через впровадження моделі соціальних послуг. Серед завдань проекту було, окрім іншого, дослідження стану забезпечення територіальних громад соціальними працівниками, спектру соціальних послуг, що надаються в громаді, врахування реальних потреб 
населення у соціальній допомозі (МБО Партнерство «Кожній дитині», 2019).

Дослідженням було охоплено 245 прогнозованих територіальних громад в Україні. Оскільки більшість громад не володіла інформацією для прийняття відповідних рішень про необхідні послуги, була застосована спеціальна методика оцінювання потреб населення у соціальних послугах. Відповідний інструмент моніторингу потреб населення у соціальних послугах розробили та протестували у Консорціумі Oxford Policy Management за участі Партнерства «Кожній дитині», у співпраці з ЮНІСЕФ, та за фінансової підтримки Європейського Союзу. Агрегований індекс забезпечення населення соціальними послугами населення ОТГ визначається сукупністю показників: індекс забезпечення соціальними послугами дітей i сімей 3 дітьми; індекс забезпечення соціальними послугами альтернативного догляду дітей-сиріт та дітей, позбавлених сімейного піклування; індекс забезпечення соціальними послугами осіб похилого віку; індекс забезпечення соціальними послугами осіб 3 інвалідністю; індекс забезпечення соціальними послугами осіб, які потребують адаптації та інтеграції (реінгтеграції); індекс забезпечення соціальними послугами осіб, які потребують екстренного чи кризового втручання (МБО Партнерство «Кожній дитині», 2019, с. 28).

Надання інтегрованих соціальних послуг відображає високий рівень життєздатності громади. Адже означення «інтегровані» в цьому контексті передбачає насамперед забезпечення умов для реалізації потенціалу кожного члена громади, розглядає кожного індивіда як ресурс (Попик, 2016). Це у свою чергу робить громаду сильнішою та здатною вирішувати проблеми та забезпечувати потреби усіх своїх громадян. Якщо розглянемо процес децентралізації в Україні та об'єднання територіальних громад, тут громада не лише робить все, що входить до ії обов'язків і можливостей, а й повинна залучити для досягнення своїх цілей ресурси та можливості 3 доступних джерел, що включатиме самого отримувача послуг i його оточення (Навчальні матеріали Всеукраїнського семінару, 2019). Ці погляди до організації інтегрованих соціальних послуг відображені в навчальнометодичному комплексі «Інтегровані соціальні служби: теорія, практика, 
інновації», де інтегрований підхід розглядають як «спосіб ставлення до індивіда та ведення справ стосовно нього, в ході застосування якого не тільки індивід адаптується до громади, але й громада робить необхідні кроки, докладає певних зусиль, аби пристосуватися до нього» (Звєрєва та ін., 2007, с. 70-71). Тому громада має бути гнучким середовищем, готовим приймати будь-яких своїх членів незалежно від їхніх потреб: чи це особа 3 особливими освітніми потребами, чи особа, що має проблеми зі здоров'ям різного характеру тощо. У дослідженні розвитку системи інтегрованих соціальних послуг в громаді Л. Ільчук (2018) подає визначення інтегрованих послуг як «концепцію надання послуг, в якій окремі блоки послуг скоординовані між собою, і яка спрямована на забезпечення економічної ефективності, поліпшення якості та підвищення рівня задоволеності отримувачів і надавачів» (Ільчук, 2018, с. 116).

Експерти проекту «Громада для людини: підвищення компетентності громад для розвитку соціальних послуг», серед іншого, вивчають питання цінностей, принципів та концептуальних засад у моделі інтегрованих соціальних послуг в об’єднаних територіальних громадах (ОТГ). Цінностями, на яких має будуватися система надання соціальних послуг на рівні ОТГ, за словами дослідників, мають бути: безпека дитини; сім'я як найкраще середовище для розвитку дитини; батьківство як важливий обов'язок; поважна та гідна старість; кожен житель громади як ресурс; самоорганізація мешканців громади; відповідальна громада. Упровадження інтегрованої системи надання соціальних послуг має грунтуватися на комплексі основних та робочих принципів, які дозволять забезпечити якісні управлінські рішення, спрямовані на розвиток соціальних послуг, системність, послідовність та узгодженість дій у процесі їх надання. Інтегрована система надання соціальних послуг $\epsilon$ загальновизнаним та високоефективним підходом до організації надання соціальних послуг i задоволення потреб громадян. Ї̈̈ суть полягає в узгодженні та координуванні функцій і заходів суб’єктів різних рівнів управління (рівень «системи»), які, працюючи синхронно та узгоджено, забезпечують комплексний та економічно ефективний підхід до розв'язання проблемних ситуацій, попередження та/чи усунення соціальних ризиків і вразливості громадянина 
(рівень «людини») (Навчальні матеріали Всеукраӥнського семінару, 2019, с. 24-25).

Таким чином, інтегровані соціальні послуги в громаді - це комплекс інноваційних системних спеціалізованих послуг спрямованих на захист прав клієнтів, які, важливо, надаються у відповідь на потреби членів громади і передбачають тісну взаємодію спеціалістів соціальних служб між собою та 3 клієнтами. Розуміємо, що комплексність, інноваційність, системність та спеціалізація у процесі надання соціальних служб не можливі без мультидисциплінарного підходу.

Відповідно до такого підходу розуміння інтегрованих соціальних послуг нам важливо з'ясувати контекст надання послуги здоров'єзбереження в громаді, оскільки здоров'я належить до питань основних прав людини і соціальної справедливості, які є ключовими для соціальної роботи. В Законі України «Про соціальні послуги» (вступить в дію 31 січня 2020 року) не визначено конкретно соціальну послугу здоров'язбереження громади, адже збереження здоров'я - це комплексний процес, який забезпечується сукупністю різних соціальних, медичних та освітніх послуг (2019).

У згаданому Законі соціальні послуги в громаді, що передбачають здоров'язбереження, включають: соціальну профілактику, послуги представництва в громаді, кризове та екстрене втручання, соціальний супровід / патронаж, надання притулку, догляд вдома, денний догляд, підтримане проживання.

Однією з перших є послуга соиіальної профілактики, яка передовсім надається клієнтам в кризовому періоді: особам або сім'ям в складнихз життєвих обставинах (СЖО); людям, які мають алко-, наркозалежність або соціально небезпечні хвороби. Профілактика може бути первинною, вторинною та третинною. Однак первинний рівень цієї послуги найдешевший варіант попередження негативних явищ щодо здоров'я, його цільовою аудиторією $є$ не лише конкретні клієнти, а всі мешканці громади. На первинному рівні профілактики діяльність зі здоров'язбереження передбачає: інформування про здоров'я, формування здорового способу життя, закладення основ усвідомленого та відповідального батьківства, навчання дієвих стилів батьківської поведінки, інформування про наслідки 
ризикованої поведінки тощо. Даний рівень соціальної профілактики стосовно здоров'язбереження передбачає також інформування сімей про спектр медичних, культурних, спортивних та соціальних послуг державних та громадських організацій, що наявні в громаді.

Вторинна профілактика зі здоров'збереження націлена на запобігання наслідкам ризикованої щодо здоров'я і соціального добробуту особи чи сім’ї поведінки, такої як розвиток залежностей, інфікування низкою небезпечних для здоров'я та життя інфекцій тощо. Акцент потрібно робити на посилення підтримуючого середовища. Здоров'язбереження на третинному рівні передбачає роботу соціального працівника на подолання залежностей, інших проблем зі здоров'ям. Другий та третій рівень профілактики, окрім самої профілактики, доповнюється рештою соціальних послуг.

Отримувачами послуги представництва інтересів $є$ особи 3 інвалідністю чи з іншими проблемами здоров'я (ВІЛ/СНІД, туберкульоз, алко- наркозалежність тощо). Надання цієї послуги передбачає сприяння у забезпеченні доступу до ресурсів і послуг за місцем проживання/ перебування, встановленні зв'язків 3 іншими фахівцями, службами, організаціями, підприємствами, органами, закладами, установами тощо. Послуга представництва інтересів дуже важлива для клієнтів із проблемами здоров’я, зокрема із соціально небезпечними хворобами, оскільки їхні права часто порушуються, вони зазнають дискримінації, особливо у закладах охорони здоров'я.

Виникнення обставин, що загрожують життю, здоров’ю особи чи дитини (у сім’і в СЖО) - це підстава для кризового та екстреного втручання. Здоров'язбережувальна функція полягатиме у наданні психологічної допомоги; допомозі в організації взаємодії 3 іншими фахівцями та службами; представництві інтересів, корекції сімейних стосунків; допомозі в отриманні безоплатної правової допомоги; особливо в організації надання невідкладної медичної допомоги; організації надання притулку.

Соиіальний супровід/ патронаж - це за своӥм змістом комплексна соціальна послуга. Вона передбачає детальний аналіз проблем клієнта, в тому числі проблем зі здоров'ям, планування та контроль дій клієнта на 
шляху до задоволення своїх потреб. Наголос робиться на знаходженні можливостей і власних ресурсів задля подолання негативної ситуації.

Серед завдань, що має розв'язувати соціальний працівник, надаючи послугу соціального супроводу: обстеження, оцінка потреб, визначення шляхів вирішення основних проблем; складання індивідуального плану соціального супроводу; залучення отримувача послуги до виконання індивідуального плану; оцінка результатів виконання індивідуального плану; регулярні зустрічі чи відвідування отримувача послуги з метою моніторингу виконання поставлених завдань; сприяння в отриманні інших послуг; допомога в усвідомленні значення дій та/або розвиток вміння керувати ними; навчання і розвиток навичок; психологічне консультування; психологічна підтримка. Наочним прикладом надання соціального супроводу в контексті здоров'язбереження $\epsilon$ діяльність соціальних працівників Благодійної організації «100\% життя» м. Львів. У роботі з ВІЛінфікованими та хворими на СНІД клієнтами, хворими на туберкульоз, фахівці здійснюють соціальний супровід керуючись усім комплексом вище перерахованих завдань соціальної послуги.

Послуга надання притулку, окрім прямого забезпечення житлом на певний визначений період часу, передбачає також оцінку інших потреб клієнта, зокрема, організацію отримання медичних послуг, медичного обстеження; психологічне консультування; допомогу в організації взаємодії 3 іншими фахівцями, службами. Користувачі послуги - це люди без певного місця проживання; жінки, які зазнали насильства в сім’ї; сім’ї в СЖО, в яких збереження і підтримка здоров'я повинні бути пріоритетним.

Люди з інвалідністю; люди похилого віку; одинокі особи, які не мають родичів, однозначно потребують послуги догляду вдома. Ця послуга передбачає допомогу в самообслуговуванні, пересуванні в побутових умовах, веденні домашнього господарства, в організації взаємодії з іншими фахівцями та службами, навчання навичок самообслуговування; допомогу в забезпеченні технічними засобами реабілітації, навчання навичок користування ними; психологічну підтримку. Дії соціального працівника задля збереження здоров’я в контексті цієї послуги повинні спрямовуватися на організацію мультидисциплінарної команди. Соціальний робітник, 
медична сестра, лікар, фізичний терапевт, ерготерапевт, психолог та інші фахівці - це команда професіоналів, що в комплексі надають послугу догляд вдома. Послуга денного догляду за своїм змістом не відрізняється від догляду вдома, єдина відмінність - клієнт, його можливості та особливості, а також місце надання послуги.

Підтримане проживання надається бездомним особам, особам похилого віку та особам з інвалідністю. Контроль та підтримка здоров'я у закладах, що забезпечують підтримане проживання, це невід'ємний елемент у діяльності соціального працівника.

Усі перелічені допомоги - це лише основний пакет соціальних послуг зосереджених у громаді, в якому простежується здоров'язбережувальна діяльність. Ці соціальні послуги можуть надаватися комунальними i недержавними суб'єктами, фізичними-особами підприємцями, громадськими та релігійними організаціями тощо. Зрозуміло, що забезпечення цього процесу неможливе без кваліфікованих спеціалістів вужчого профілю, які в системі надання деяких послуг є ключовими. Тому завданням громад $є$ залучення таких спеціалістів до надання соціальних послуг. Варто зазначити, що хоч Закон «Про соціальні послуги» оновився та невдовзі вступить у дію, стандарти надання цих послуг наразі залишаються старими. Тому відповідальністю громади є адаптація Закону та реалізація саме такої послуг, яка необхідна членам громади, акцентуючи на визначених потребах та ресурсах, що мають усі члени громади.

Висновок: Вивчення результатів згаданого проекту та сучасний стан забезпечення територіальних громад соціальними послугами дає підстави стверджувати, що сьогодні існує високий рівень потреб громади у професіоналах із соціальної роботи, які здатні надавати інтегровані соціальні послуги у громаді на засадах збереження та зміцнення здоров'я. Для цього слід забезпечити умови для здійснення професійної підготовки кваліфікованих соціальних працівників з надання інтегрованих соціальних послуг у громаді, що грунтуються на засадах здоров'єзбереження. Для цього слід залучати потенціал кафедр соціальної роботи 3 пропозиціями як традиційних магістерських освітніх програм із соціальної роботи, так i програм підготовки фахівців соціальної роботи на засадах дуальної освіти. 